Huliaieva, H., Pasichnyk L., Tokovenko, I., Kalinichenko, A., Patyka1, V., Bohdan, M., Patyka, M., Maksin, V. (2021): Influence of citrate nanoparticles on photochemical activity, resistance to pathogens and productivity of wheat. Agriculture and Forestry, 67 (4): 15-33. doi:10.17707/AgricultForest.67.4.02

DOI: 10.17707/AgricultForest.67.4.02

\begin{abstract}
Hanna HULIAIEVA ${ }^{1}$, Lidiia PASICHNYK ${ }^{1}$, Irina TOKOVENKO ${ }^{1}$, Antonina KALINICHENKO ${ }^{2 *}$, Volodymyr PATYKA ${ }^{1}$, Mykhailo BOHDAN ${ }^{1}$, Mykola PATYKA ${ }^{3}$, Viktor MAKSIN ${ }^{3}$
\end{abstract}

\title{
INFLUENCE OF CITRATE NANOPARTICLES ON PHOTOCHEMICAL ACTIVITY, RESISTANCE TO PATHOGENS AND PRODUCTIVITY OF WHEAT
}

\begin{abstract}
SUMMARY
In field experiments, increase the quantum efficiency of PSII (Fv/Fp), the Rfd-values (the chlorophyll fluorescence vitality indices) and the content of photosynthetic pigments in wheat leaves at pretreatment of wheat seeds with solutions of citrate nanoparticles has been shown. The green weight of plants at bacterial and phytoplasmas infecting at pretreatment with solutions of citrate nanoparticles, was increase, than without pre-treatment, in order: GeNPs $>$ I$\mathrm{Se}>\mathrm{SeNPs}>\mathrm{VNPs}$ as it has been shown. The Fv/Fp-values in leaves infected with phytoplasmas of plants at pretreatment of VNPs or I-Se solutions were more, than without pretreatment. The $\mathrm{Fv} / \mathrm{Fp}$-value in leafs with bacterial infecting at pretreatment of GeNPs with compared to infected plants without pretreatment was increased has been shown. The Rfd-value in leaves at pre-sowing treatment of GeNPs or I-Se and bacterial infecting compared to infected plants without the pr-treatment was more has been shown. This value at infected plants with phytoplasmas at pretreatment of GeNPs or VNPs, compared to infected plants without pretreatment, was increased. In greenhouse experiments, Fv/Fp-values of plants leaves infected of phytoplasmas, bacteria and wheat streak mosaic virus (WSMV) at pre-treatment of solutions of citrate nanoparticles compared to infected plants without pretreatment has been increased. The pretreatment with nanoparticles GeNPs caused grain production by $15.6 \%$ increased has been shown. The weight grains/10 in plants on variant with pretreatment with Ge
\end{abstract}

\footnotetext{
${ }^{1}$ Hanna Huliaieva, Lidiia Pasichnyk, Irina Tokovenko, Volodymyr Patyka, Mykhailo Bohdan: Department of Phytopathogenic Bacteria, Zabolotny Institute of Microbiology and Virology of National Academy of Sciences of Ukraine, Acad. Zabolotny str. 154, Kyiv, 03680, UKRAINE

2 Antonina Kalinichenko *(Corresponding author: akalinichenko@uni.opole.pl): Institute of Environmental Engineering and Biotechnololgy, University of Opole, Dmowskiego str. 7-9, Opole, 45-365, POLAND

3 Mykola Patyka, Viktor Maksin: National University of Biological Resources and Natural Resources of Ukraine, Heroiv, UKRAINE

Paper presented at the $12^{\text {th }}$ International Scientific Agricultural Symposium "AGROSYM 2021".

Notes: The authors declare that they have no conflicts of interest. Authorship Form signed online.

Recieved:20/07/2021

Accepted:24/10/2021
} 
nanoparticles (with consortium of soil microorganism) and bacterial infecting were more, than without pretreatment has been shown. The weight grains/10 in plants on variant at pre-treatment of plants of nanoparticles solution and infected with phytoplasmas compared to infected plants without the pre-treatment increased in order: GeNPs $>$ I-Se $>$ VNPs $>$ SeNPs.

Keywords: Wheat, bacteriosis, phytoplasmas, WSMV, nanoparticles.

\section{INTRODUCTION}

Nanoparticles, their compounding and nanomaterial's, that created with help nanotechnologies have been actively studied in recent decades with the aim of their application in various fields of science, including crop production (Sanzari, 2019; Mittal D et al, 2020). Due to the instability of metal nanoparticles in solutions, they are stabilized, particularly, with citrates, which provides both an increase in the stability of their solutions and their high reactivity. Specialty of the reactivity of citrates of nanoparticles is that molecules with thiols or amines easily displace citrate from the surface and firmly bind to metal surfaces. Negatively charged metal nanoparticles can easily penetrate into plant cells, affecting metabolism (Ranoszek-Soliwoda et al., 2017). Shinohara S. et al (2018) fined, that nanoparticles stabilized by citric acid remain stable at high ionic strengths and therefore exist in solution as individual particles.

Various nanoparticles can be used as fertilizers, growth stimulants, antimicrobial and anti-stress agents. The protection effect of nanoparticles for plant diseases is due to both direct antimicrobial action and the activation of plant defense mechanisms (Elmer et al., 2018; Mittal D et al, 2020).

The effect of pre-seed treatment with nanoparticles and their compounds has been demonstrate by many researchers (Siddiqui, S.A., et al, 2021; Acharya P et al, 2020; Honchar L. et al, 2021; Prażak R. et al, 2020; Davydova, N.V. et al, 2020; Pereira E.S. et al, 2021; Khalaki A.M. et al, 2021).

The results investigation Siddiqui, S.A. et al (2021) showed demonstrated, that selenium in the form of nanoparticles has an order of magnitude that is less toxic than in the form of selenous acid. In studies of Acharya P et al (2020) demonstrated that seed priming with AgNPs can enhance seed germination, growth, and yield while maintaining fruit quality of watermelons. It was shown, that pre-sowing treatment of chufa tubers with nano-particles solutions of manganese, zinc, copper and iron with a concentration of $60 \mathrm{ppm}$ and reapplication of these solutions after seedling emergence significantly increased the weight of the plant (excluding the weight of seeds), and the most effective were treatments with copper and iron (Honchar L. et al, 2021). It was shown, that application of AgNPs influenced not only seed germination in the laboratory but also the dynamics of emergence of bean seedlings and their growth and development in field conditions were shown. The biological significance of the effects induced by AgNPs varied depending on the concentration of nanoparticles and on growth conditions (Prażak R. et al, 2020). 
It was found, that pre-sowing seed of spring wheat treatment by a composition of FeNPs at a concentration of 10-5\% and Zn NPs at a concentration of $10-4 \%$ contributed to a $27 \%$ increase in the seed germination energy index and root weight compared to the control (Davydova, N.V. et al, 2020).

Seed nano-priming can change seed metabolism and signaling pathways, affecting not only germination and seedling establishment but also the entire plant lifecycle, that the promotion of stress and diseases resistance out coming in the reduction of pesticides and fertilizers. Thus, use of nano-based technology for seed treatment has big potential move to a more sustainable agriculture (Pereira E.S. et al, 2021). It was shown, that nano-priming increased seed germination, seedling growth and development, vigor, rate of seedling emergence and subsequent performance in most of the medicinal and forage plants. While, also negative effects of nano-priming on seed germination, seedling and plant growth traits were observed (Khalaki A.M. et al, 2021).

The effect of seed treatment with nanoparticles of $\mathrm{Au}, \mathrm{Ag}, \mathrm{Cu}, \mathrm{Zi}, \mathrm{Fe}, \mathrm{Mn}$, $\mathrm{Mg}, \mathrm{Ce}, \mathrm{Ti}, \mathrm{Si}$ and their oxides on plants in more was studied (Ruttkay-Nedecky et al.,2017; Mittal D et al, 2020). At the same time, the effect of selenium and esp germanium, vanadium and nanoparticles on the physiological and biochemical properties of plants has been little studied. Although these elements are not essential for plants, they have different beneficial properties.

For example, Ge NPs have the advantages of low toxicity and excellent biocompatibility. it was found that, was discovered that Ge NPs have the intrinsic peroxidase-like catalytic activity. Compared with natural enzyme (horseradish peroxidase, HRP), Ge NPs maintain higher catalytic stability after treatment at different $\mathrm{pH}$, temperature and ionic strength (Hu J. et al, 2019).

In plants, low levels of $\mathrm{V}$ have beneficial effects on plant growth and development. Nevertheless, excessive $\mathrm{V}$ provokes numerous deleterious effects (Chen L. et al, 2021).

Physiological function of selenium in plants is not fully-known and the physiological reactions of various plants to selenium vary very much. At the same time, fortification of crops with selenium can be one of the ways enabling to increase the content of selenium in human and animal food chain (Ježek P., 2012). Iodine, silicon, and selenium are considered elements not essential for the metabolism of plants, but these elements (as traces) are vital for humans. It has been found that by using I, Se, and Si in crop plants, applied in seeds, plants, or fruits, favorable responses are obtained such as increased growth and tolerance to stress (due to with a higher concentration of antioxidants). In this connection, the use of these elements is a useful technique for the nutritional improvement of crop plants, both in antioxidant level and biofortification (Medrano-Macías J., 2018). Iodine (I) and selenium (Se) are beneficial elements, as both play important roles in humans, that is why often using plant biofortification by agrotechnical or biotechnological approaches in order to improve, among other things, the accumulation this nutrients in food and fodder (Smolen S. et al, 2016). 
Therefore, the aim of our work was investigation of influence of citratestabilized of nanoparticles of germanium, vanadium and selenium on photochemical activity, chlorophyll content, resistance to pathogens and productivity of plants wheat.

\section{MATERIAL AND METHODS}

For experiments in field conditions and in the greenhouse were used: $0.75 \%$ solutions of citrate nanoparticles $\mathrm{Ge}-\mathrm{GeNPs}(\mathrm{Ge}$ content: $500 \mathrm{mg} / \mathrm{l})$ and citric acid; $0.75 \%$ V NPs (V content $300 \mathrm{mg} / \mathrm{l}$ ) and citric acid; 1\% Se NPs (Se content: $100 \mathrm{mg} / \mathrm{l}$ ) and citric acid; («Nanomaterials and nanotechnology» Ltd, Ukraine); $0.5 \%$ BP I-Se (a preparation of biologically active iodine in a complex with solution Se) (preparation "Jodis-concentrate plus Se") consists of purified water enriched with polyatomic ions $\mathrm{I}, 80 \mathrm{mg} / \mathrm{dm}^{3}$, Se citrate, intended as a biologically active food additive (SPC «Iodis», Ukraine).

In the field's conditions, wheat plants (Triticum aestivum L.) variety`s Pecheryanka were grown on experimental plot of the D.K. Zabolotny Institute of Microbiology and Virology of NASU in 2019-2020. The area of the experimental plot is $50 \mathrm{~m}^{2}$, the soil is sod-podzolic. Repetition in the experiment four times.

In the soil before sowing was added consortium of soil-forming microorganisms (the biological product (BP) "Extrakon" (Ukraine)). BP Extrakon consists of a consortium of soil cellulosolytic and heterotrophic microorganisms inoculated into a peat-like substrate, which are in a functionally active state and are closely connected by trophic bonds: (Sporocytophaga mixococcoides, Sorangium cellulosum, Cellvibrio mixtus, Trichoderma viridae, Pseudomonas fluorescens, P. putida, Bacillus subtilis, B. sphaericus, B. megaterium, B. pumilus).

The general scheme field's and greenhouse`s experiments with using presowing treatment of citrate nanoparticles: 1 - control (intact plants); $2-1$ $\mathrm{mg} / \mathrm{lSeNPs}+$ addition in soil of BP Extrakon; $3-0,8 \mathrm{mg} / \mathrm{l} \mathrm{I}-\mathrm{Se}$ solution+ addition in soil of BP Extrakon; $4-2,25 \mathrm{mg} / \mathrm{l}$ VNPs solution addition in soil of BP Extrakon; 5 - 3,75 mg/l GeNPs solution addition in soil of BP Extrakon.

Bacterial culture Pseudomonas syringae pv. atrofaciens D13 was isolated from clay-brown spot-strokes on a leaf-sheath of wheat, that was collected in the Dnipropetrovsk region. Isolation of bacteria from plant samples, inoculation and cultivation of them on solid medium and preparation of a bacterial suspension were performed according to generally accepted techniques (Patyka et al., 2017).

In the greenhouse`s and field`s experiments, artificial inoculation of Pecheryanka`s variety spring wheat plants in the boot stage was carried out with bacterial suspension of the strain of $P$. syringae pv. atrofaciens D13 (the causal agent of basal glume rot of cereals). Density of the suspension was $1 \times 10^{9}$ $\mathrm{CFU} / \mathrm{ml}$. Artificial inoculation of plants was done by injecting a bacterial suspension into a stem in 10-fold repeatability on each of the variant.

In the greenhouse`s and field`s experiments phytopathogenic phytoplasma 
of Acoleplasma laidlawii var. granulum 118 UKM BM-34 was cultured on a liquid nutrient medium CM IMB-72 $(\mathrm{pH}=7.8)$ in a thermostat at $32{ }^{\circ} \mathrm{C}$ for 72 hours. Artificial inoculation with phytoplasma of A. laidlawii var. granulum 118 UKM VM-34 in the boot stage was performed with the method of subepidermal injection in the steam.

In the greenhouse, inoculation of wheat plants with freshly prepared viruscontaining material was carried out in the phase of the two true leaves, by the method of mechanical inoculation of leaves with preliminary dusting with the carborundum. Isolation of viral material was performed by homogenization of freshly cut leaves of diseased plants with clear symptoms of the wheat streak mosaic virus (WSMV) with the addition of $0.1 \mathrm{M}$ phosphate buffer $\mathrm{pH}$ 7.0. The plant homogenate was filtered through a nylon sieve and used for mechanically infect of plants. Infection of plants was carried out of a glass spatula or fingers in disposable gloves soaked in inoculum. Excess inoculum was washed off with water (Diagnose von Krankheiten und Beschädigungen an Kulturpflanzen. Diagnosemethoden, 1984).

The photochemical activity of leaves was determined with the biophysical method of chlorophyll $a$ fluorescence induction with using a portable device "Florotest" (Ukraine).

The device is equipped with a liquid crystal display $(128 \times 64$ pixels $)$ and a remote optoelectronic sensor with a wavelength of $470 \pm 15 \mathrm{~nm}$, the area of the irradiation spot not less than $15 \mathrm{~mm}^{2}$ and illumination within it not less than 2.4 $\mathrm{W} / \mathrm{m}^{2}$. The spectral range of fluorescence intensity measurements is in the range from 670 to $800 \mathrm{~nm}$. The data measured by the device was transferred to a PC via the USB port of the computer using the software "Floratest", which comes with the device and allows you to display this data in tabular or graphical form. Measurement of fluorescence induction was carried out on flag leaves of wheat in the heading-flowering phase. Dark adaptation of leaves before measurements was in range: 6-20 minutes. Replications measurements on each variant - threefold. The evaluation of the influence of experimental factors was performed by changes in the value of the quantum efficiency parameter PSII: $\mathrm{Fv} / \mathrm{Fp}(\mathrm{m})(\mathrm{Fv}=$ $\mathrm{Fm}(\mathrm{p})-\mathrm{F}_{0}$ ), where $\mathrm{F}_{0}$ - the minimum fluorescence; $\mathrm{F} \mathrm{m}(\mathrm{p})$ - maximum (peak) fluorescence, $\mathrm{Fv}$ - variable fluorescence; $\mathrm{Fs}$ - is the steady-state Chl fluorescence; Rfd-values - the chlorophyll fluorescence decrease ratio (chlorophyll fluorescence vitality indices): $\mathrm{Rfd}=(\mathrm{Fm}(\mathrm{p})-\mathrm{Fs}) / \mathrm{Fs}$ (Sharma et al., 2015; Lichtenthaler et al., 2007; Huliaieva, et al. 2018).

The pigments contents in flag leaf of wheat in field`s experiments were measured with the extraction method in DMSO with followed by spectrometry (Hisox, Israelstam., 1979).

Accounting for grain productivity in the experimental plots was done at the end of the growing season at full grain maturity. Statistical processing of the obtained results was performed using computer programs MS Excel. 


\section{RESULTS AND DISCUSSION}

It is known that the method of induction of chlorophyll fluorescence is quite sensitive and allow quickly and non-invasively assess photochemical changes under the influence of various factors (Maxwell, Johnson, 2000). It is known that the action of stressors leads to changes of $\mathrm{Fv} / \mathrm{Fm}(\mathrm{p}$ ) (quantum efficiency of PSII), which reflects the damage and inactivation of PSII (often called photoinhibition). Changes in this indicator are often used to assess the impact of stress factors (Murchie, Lawson, 2013; Sharma, et al., 2015). The results investigation of Peña-Olmos et al. (2013) showed that toxicity caused by an excess of iron induced an increased level of stress in the broccoli plants, causing decreased of the value of photosystem II's (PSII) maximum quantum yield $(\mathrm{Fv} / \mathrm{Fm})$. The maximum quantum efficiency of photosystem II was inhibited in citrus plants under saline stress (Sousa J.R.M., et al, 2016). In investigations Jia M. et al (2019) were shown, that the Fv/Fm of wheat leaves was tended to increase with increasing $\mathrm{N}$ application. In our field's experiments, at the portable field chlorophyll fluorometer using, was shown increase quantum efficiency of the PSII $(\mathrm{Fv} / \mathrm{Fm})$ at pre-treatment of citrates of nanoparticles solution in order: Ge (17.5\%)>I-Se $(8.8 \%)>\mathrm{Se}(7.0 \%)$ have been shown (Fig.1 a). This is indicates rise amount of photochemically reactive centers and an improvement in the absorption of light quanta by PS II of the photosynthetic apparatus of wheat plants.

The Rfd-value for effect of application investigating of nanoparticles give important information, as is indicator of photosynthetic activity of leaves (Lichtenthalera, Babania, 2000). The Rfd-value also has been called vitality index of green leaves (Haitz, Lichtenthaler, 1988). Many researchers often use the Rfd parameter to assess the effect of stress factors on the photosynthetic apparatus. In investigations of Perera-Castro et al (2018) the Rfd-value has been demonstrated as a more sensitive parameter for thermic damage assessment. According to Rfdvalues, the photosynthetic apparatus, independent of symbiotic status, becomes increasingly damaged under progression of drought, which was accompanied with a sharp drop in stomatal gas exchange parameters (Polcyn W. et al, 2019). In our results was shown, that the Rfd-values increased at pre-treatment of citrates of nanoparticles solution of GeNPs by $11.4 \%$. This is value have been equal to control at pre-treatment of wheat of I-Se and reduced at pre-treatment of VNPs (23.9\%) (Fig 1 b).

In results investigations Wang Z. B. et al (2018) was suggested that low concentrations of $\mathrm{GeO}_{2}$ could alleviate photoinhibition and $5.0 \mathrm{mg}\left(\mathrm{GeO}_{2}\right) \mathrm{L}^{-1}$ was the most effective, due to its function of scavenging free radicals and lowering accumulation of reactive oxygen species, which was proven with higher antioxidant enzyme activities. The application of $5 \mu \mathrm{M} \mathrm{V}$ increased plant growth, induced floral bud development, and accelerated flowering of pepper plants was shown (García-Jiménez A., 2018). A chlorophyll assay which was conducted of the chlorophyll $a+b$ in leaves increased on variants pre-treatment in order: ISe $>$ GeNPs $>$ VNPs $>$ SeNPs has been shown (Table 1). 
Table 1. Photosynthetic pigments content in flag leaves of wheat plants at the pre-sowing treatment of solutions of citrates nanoparticles and application of the BP Extrakon

\begin{tabular}{ccc}
\hline Variants & Chl. $a+b$ & Car. \\
\hline Control (without treatment) & $1,06 \pm 0,05$ & $0,17 \pm 0,009$ \\
Pre-treatment of 1mg/l SeNPs+Extr. & $1,68 \pm 0,08$ & $0,52 \pm 0,015$ \\
Pre-treatment of 0,8 mg/l I-Se+Extr. & $2,49 \pm 0,16$ & $0,30 \pm 0,010$ \\
Pre-treatment of 2,25 mg/l & & \\
VNPs+Extr. & $2,30 \pm 0,14$ & $0,58 \pm 0,03$ \\
Pre-treatment of 3,75 mg/GeNPs+Extr. & $2,42 \pm 0,12$ & $0,45 \pm 0,02$ \\
\hline
\end{tabular}
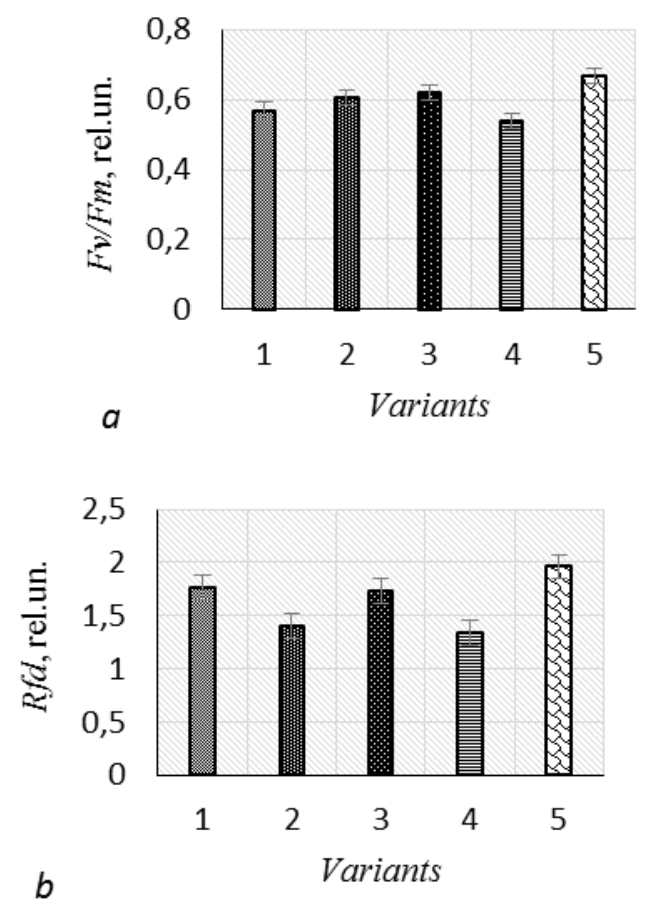

Figure 1. The quantum efficiency of PSII (Fv/Fm) (a) and Rfd-values (chlorophyll fluorescence vitality indices) in wheat leaves at the pre-treatment of wheat seeds with solutions of citrate nanoparticles and application BP Extrakon (Extr.) (heading stage): 1 - Control; 2 - SeNPs+Extr.; 3 - I-Se+Extr.; 4 VNPs+Extr.; 5 - GeNPs+Extr. 


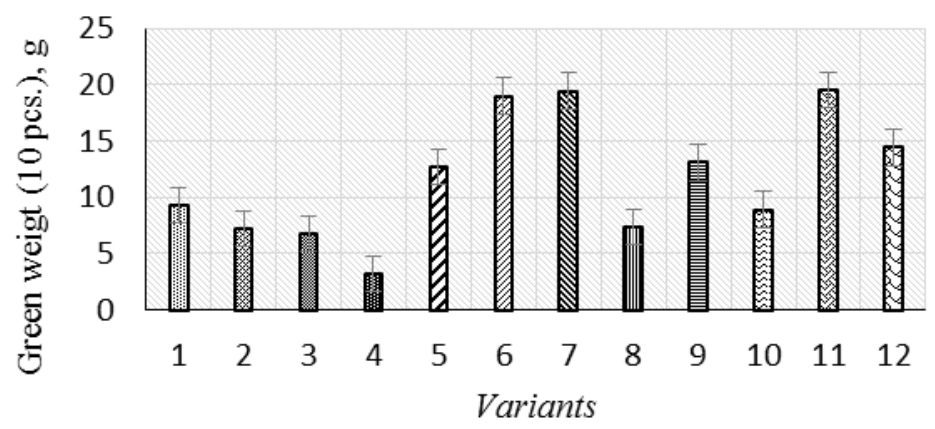

Figure 2. Influence pre-treatment of NPs on the green weight of wheat plants (10 pcs., booting stage): 1 - Control; 2 - D13; 3 - 118; 4 - VNPs, Extr.+D13; 5 VNPs, Extr.+118; 6 - GeNPs, Extr.+D13; 7 - GeNPs, Extr.+118; 8 - SeNPs, Extr.+D13; 9 - SeNPs, Extr.+118; 10 - I-Se, Extr.+D13; 11 - I-Se, Extr.+118; 12 - I-Se, Extr.+(D13+118).

The content carotenoids, which protect of chlorophyll molecules from photooxidation, increased in order: VNPs $>$ SeNPs $>$ GeNPs $>$ I-Se (see table 1). In investigations Mohamed T (2021) was shown, that the BioSeNPs increased of content of photosynthetic pigments (chlorophyll and carotenoids), parameters of gas exchange, i.e., transpiration ( $\mathrm{Tr}$ ), net photosynthesis $(\mathrm{Pn})$ and has been strong antifungal activity. At application of $\mathrm{V}$ the chlorophyll concentration in pepper plants has been varied according to the type of plant part analyzed was shown (García-Jiménez A., 2018). In results investigations Abedini, M., Mohammadian, F. (2018) was indicated that $\mathrm{V}$ at all applied concentrations $(0,3.25,7.5$ and 15 $\mathrm{mg} \mathrm{L}^{-1}$ ) significantly decreased the plant's growth, and total protein and carotenoid contents, but increased the total chlorophyll and soluble sugars contents. Also, the obvious induction in the phenylpropanoid pathway was seen in response to $\mathrm{V}$ application. In comparison to the control, only at the simultaneous application of I + Se significantly increased of root biomass of lettuce was shown (Smoleń $\mathrm{S}$ et al, 2016).

On the other hand, in our previous studies, the antimicrobial effect of $\mathrm{V}$, Ge, I-Se nanoparticles was shown (Huliaieva H.B. et al, 2020). In this regard, further studies were aimed investigation the photochemical activity and growth of wheat plants at pre-treatmant by these nanoparticles with infecting with pathogenic phytoplasmas and bacteria. At infected of wheat plants with infectious agent of bacteriosis (Pseudomonas syringae pv. atrofaciens) and phytoplasmas (Acholepasma laidlawii var. granulum) were reduced of green weight of plants (10 pcs.) by 10.8 and $26.9 \%$ (Fig. 2).

On variants with at pre-sowing treatment of plants of citrates nanoparticles solution and bacterial and phytoplasmas infected plants versus control increased of green weight of plants in order: GeNPs $>$ I-Se $>$ SeNPs $>$ VNPs have been shown. The most significant growth of wheat biomass was in variants of the pre- 
treatment: GeNPs (with Extrakon) at infected plants with bacteria and phytoplasmas, I-Se (Extrakon) both at infected with A.laidlawii 118 and at mix infection (D13+118) has been observed (See fig. 2). The pre-treatment VNPs and SeNPs (and Extrakon) was more effectiveness at infected plants of phytoplasmas has been shown (See fig. 2). This effect from using of Ge, Se, V nanoparticles at bacterial and phytoplasmas infected plants can be explained by the induction of systemic resistance, which developed to varying degrees. It is possible due to: fruition the intrinsic peroxidase-like catalytic activity of the $\mathrm{Ge}(\mathrm{Hu} \mathrm{J}$. et al, 2019 ), induction of the phenylpropanoid pathway was inducted in response to $\mathrm{V}$ application (Abedini, M.; Mohammadian F. 2018 ) and increased of concentration of antioxidants in plants at application I and Se (Medrano-Macías J., 2018). Introduction of I, Se and SA into the nutrient solution significantly affected proline accumulation in lettuce leaves and roots was shown (Smoleń $\mathrm{S}$ et al, 2016).

In field and greenhouse experiments, two weeks after inoculation, we observed the appearance of characteristic symptoms: yellow mosaic with intermittent strokes on the leaves (on variants of virus-infected plant) (Fig. 3), dark brown spots on caulis (at bacterial infecting) (See fig. 3). The early yellowing and drying of leaves as well as ear of wheat with splay out on plants infected with phytoplasmas to milk-ripe stage have been observed (Fig. 3).
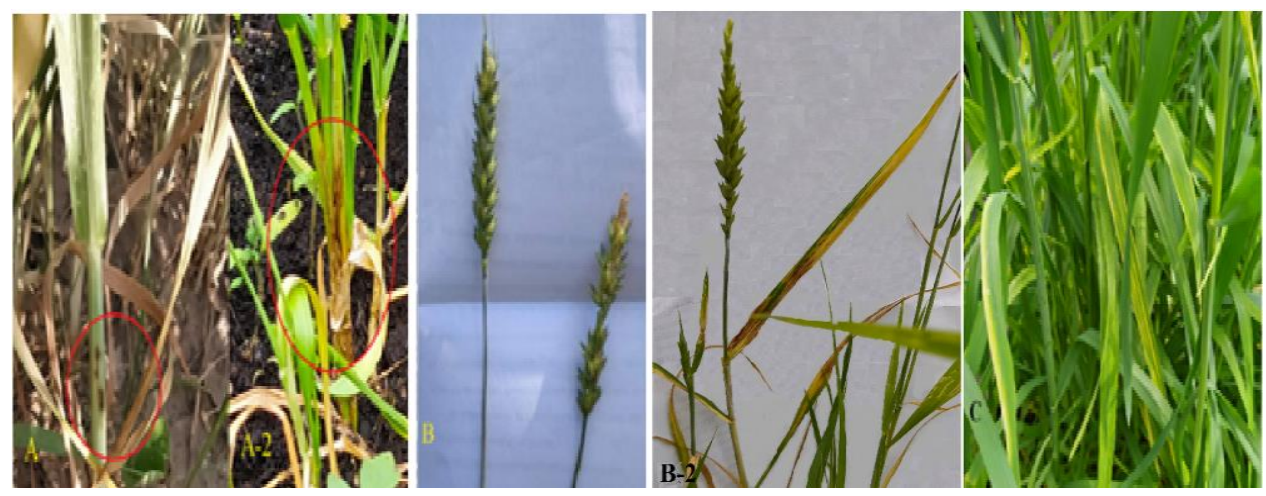

Figure 3. The characteristic symptoms of infesting: (A, A-2) - the plant wheat with bacterial infecting (P.syringae pv. atrofaciens); (B, B-2) - the wheat plant infected with phytoplasmas (A.laidlawii) (milk-ripe stage); $\mathrm{C}$ - yellow mosaic with intermittent strokes on the leaves (on variants of virus-infected plant (WSMV)).

The quantum efficiency of PSII (Fv/Fm) in leaves of plants at infected with phytoplasmas reduced by $6.3 \%$ in field's experiments. The Fv/Fm-value increased by $13.6 \%$ at phytoplasmas infected plants with pre-treatment of VNPs and with application of I-Se it value was tended to increase in compared to infected plants without treatment. In leaves of plants at pre-treatment of GeNPs and bacterial-infected the Fv/Fm-value increased compared to control on $14 \%$ 
have been detected (Fig. 4 a). Thus, using nanoparticles of V, Ge and I-Se at inoculation plants with phytoplasmas promoted an increase in the quantum efficiency of PS II in comparison with infected plants without treatment.

The Rfd-value - vitality indices of green leaves - increased in leaves of wheat at bacterial infected and decreased at phytoplasmas infected (Fig. 4 b).
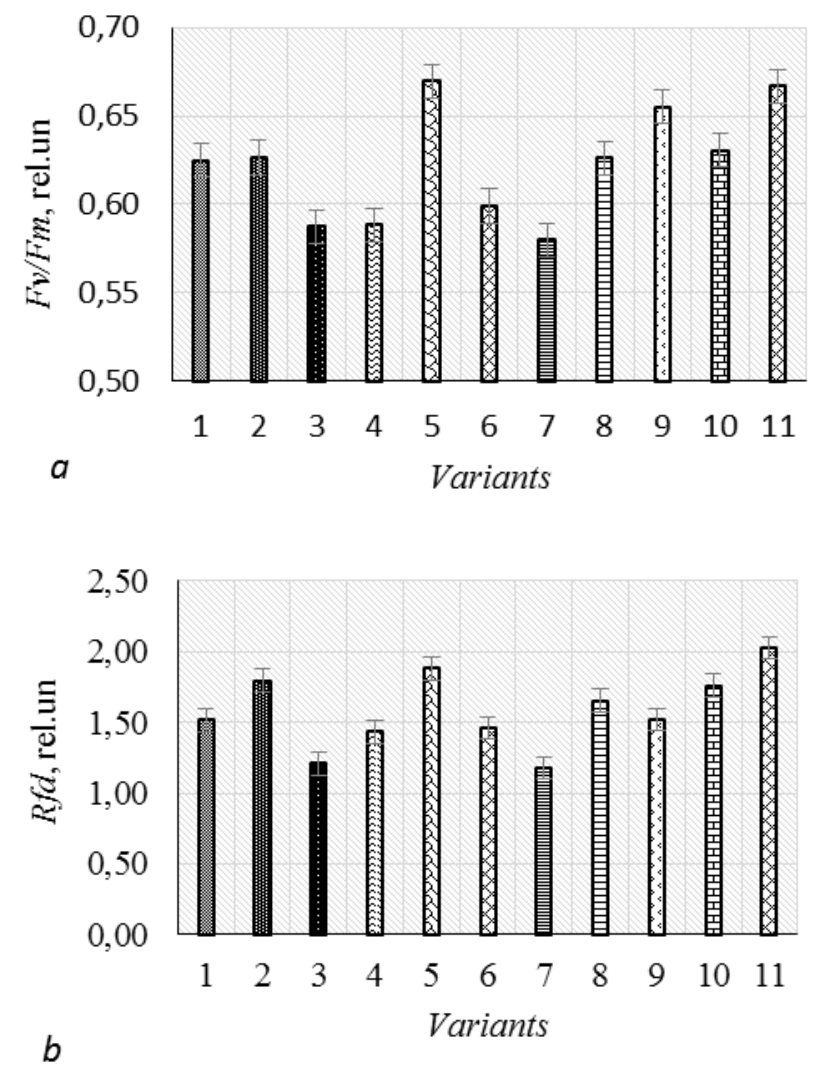

Figure 4. Influence of infected of wheat plants with infectious agent of bacteriosis (Pseudomonas syringae pv. atrofaciens) and phytoplasmas (Acholepasma laidlawii var. granulum) after pre-treatment of NPs with application of Extrakon on Fv/Fm and Rfd-values (fields experiments, heading stage): 1 - Control; 2 - Pseudomonas syringae pv. atrofaciens D13; 3 Acholepasma laidlawii var. granulum 118; 4 - VNPs, Extrakon (Extr.) + D13; 5 - VNPs, Extr. +118; 6 - SeNPs, Extr. + D13; 7 - SeNPs, Extr. + 118; 8 - I-Se, Extr. +D13; 9 - I-SeNPs, Extr.+ 118; 10 - GeNPs, Extr.+ 118; 11 - GeNPs, Extr.+D13.

In investigation Berger $\mathrm{S}$. et al (2007) decline of the $\mathrm{F}_{\mathrm{V}} / \mathrm{Fm}$ and the Rfd parameter was detected from $24 \mathrm{~h}$ after the inoculation with bacteria $P$. syringae.

Previous studies (Gulyaeva A.B. et al, 2016) was founded that when infected wheat plants with four pathogenic strains of $P$. syringae pv. atrofaciens (different in aggressiveness), from 13 to 16 days gradually decreased the 
maximum quantum efficiency of photochemistry PS II (Fv /Fm). Whereas 19 days after the inoculation, the value of this parameter was almost no different from the control. In the same time an increase in the Rfd-value in plants leaves bacterial-infected, together with a decrease in plant biomassmay be is associated with redistribution of assimilates and the inclusion of protective mechanisms against the development of infection. In particular, it may be associated with an increase in the process of photorespiration (antagonistic to photosynthesis), which is involved in protection photosynthetic apparatus from stress (Wingler et al., 2000; Timm, 2016).
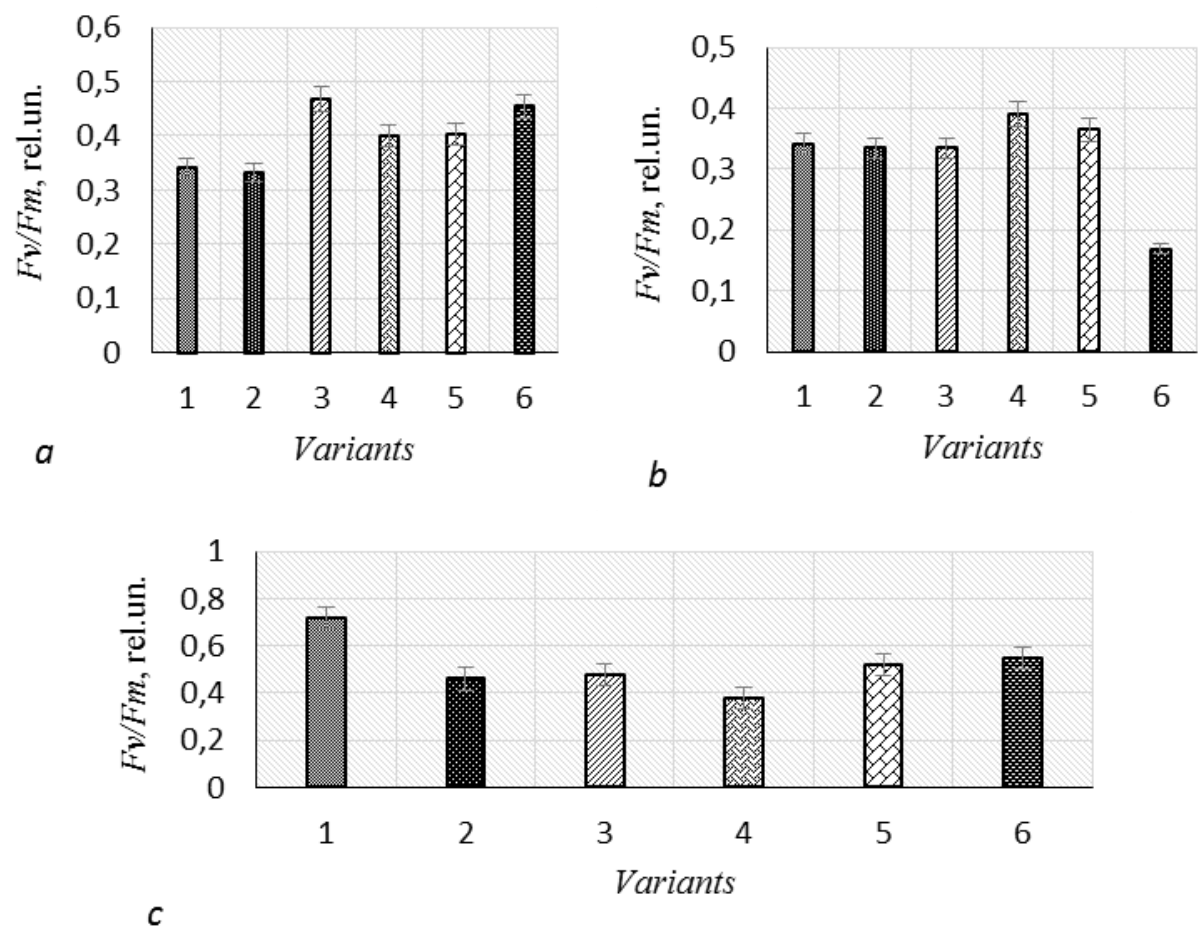

Figure 5. Influence of infected of wheat plants with infectious agent of bacteriosis (Pseudomonas syringae pv. atrofaciens), phytoplasmas (Acholepasma laidlawii var. granulum) and WSMV after pre-treatment of NPs with application of Extrakon on Fv/Fm-values (greenhouse experiments, heading stage): (a) 1 - Control; 2 - D13; 3 GeNPs, Extr.+D13; 4 - SeNPs, Extr.+D13; 5 - VNPs, Extr.+D13; 6 - I-Se, Extr.+D13. (b) 1 - Control; 2 - Phytoplasma (phytopl.); 3 - GeNPs, Extr.+Phytopl.; 4 - I-Se, Extr.+Phytopl.; 5 - VNPs, Extr.+Pytopl.; 6 - SeNPs, Extr.+Phytopl. (c) 1 Control; 2 - WSMV; 3 - Extrakon+SeNPs+WSMV; 4 - Extrakon+I-Se+WSMV; 5 VNPs, Extr.+WSMV; 6 - GeNPs, Extr.+WSMV.

The Rfd-values in the leaves of infected plants with phytoplasmas an increased at pre-sowing treatment with VNPs (55.6\%), GeNPs (45.5\%) and I-Se $(25.6 \%)$ were observed. This value increased in leaves at bacterial-infected plants at pre-sowing treatment of GeNPs (12.8\%) (See fig. 4 b). 
In greenhouse experiments increase of the $\mathrm{Fv} / \mathrm{Fm}$-value on variants of pretreatment with: I-Se (14.7\%), VNPs (5.9\%) (at phytoplasmas infected plants), GeNPs $(42.4 \%)>\mathrm{I}-\mathrm{Se}(36.4 \%)>\mathrm{V}$, Se $(21.2 \%)$ (at bacterial infected plants) and GeNPs (19.6\% )>VNPs (13.0\% ) >SeNPs (4.3\%) (at WSMV infected plants) has been shown (Fig. 5 a-c). This indicates an increase in stress resistance at presowing treatment with these nanoparticles.

In investigation (Liu Y et al, 2016) was shown, that addition of exogenous Ge to the salt solution, as well as soaking the seeds in Ge, attenuated the salt stress effects in a manner dependent on the dose of $\mathrm{Ge}$, as indicated by the increased percentage of seeds that germinated and improved seedling growth. In investigations Rojek J et al (2019) was founded, that higher rate of plant survival in the presence of $\mathrm{VOSO}_{4}$ and the relatively high photosynthetic parameters and anthocyanin contents in the cells vanadium (IV) compound can have positive effects on plants that are grown under stress conditions. The stressed plant's growth rate was the highest in Se nanoparticle concentrations of 5 and $10 \mu \mathrm{g} \mathrm{kg}$. The plant leaf plate surface area after Se nanoparticle application was almost 2 times larger compared to stressed plants grown without Se nanoparticle addition to the soil (Gudkov S.V. et al, 2020).

The grain weight $/ 10$ plants increased on variants at bacterial-infected plants and pre-treatment of GeNPs (with Extrakon) (36.2\%) (Fig. 6).

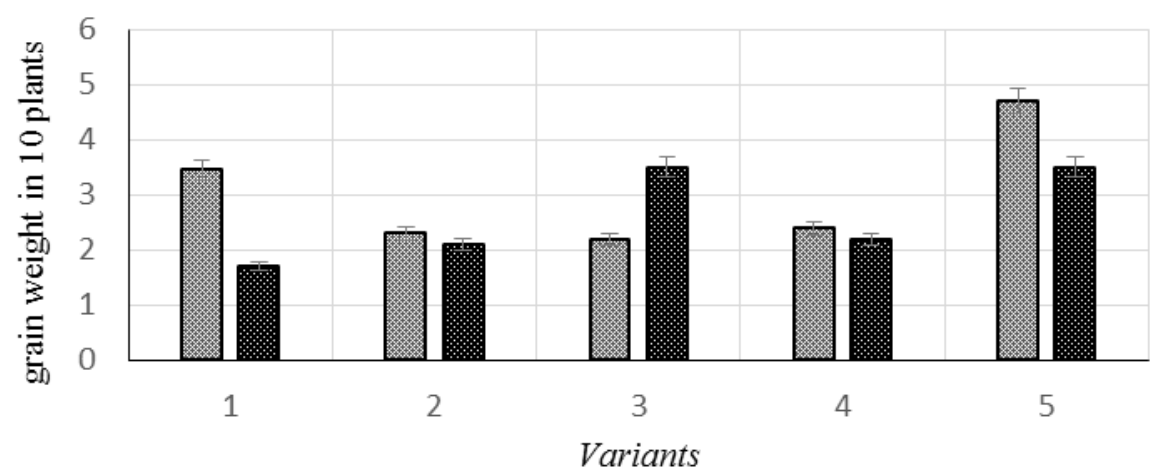

\section{@Bacteriosis Phytoplasmosis}

Figure 6. The grain mass / 10 plants during pre-sowing treatment of nanoparticles citrate solutions (with the Extracon) and bacterial and phytoplasmas infected plants: 1-bacteriosis/phytplasmosis; 2 - SeNPs+infected plants; 3 - ISe+infected plants; 4 - VNPs+infected plants; 5 - GeNPs+infected plants.

In field condition, at bacterial and phytoplasmas infected plants, heads wheat was small and unformed, with flat grain has been shown (Fig. 7 A (2-5)).

The grain production was increased by $15.6 \%$ in variants with pre-treatment with GeNPs have been shown. Whereas in other variants it decreased (Fig. 7 a). The 
weight of 1000 grains increased by $16,4 \%$ at pre-treatment of GeNPs. At pretreatment of SNPs and VNps this value was equal to control, but pre-treatment of I-Se it decreased by $10,9 \%$ (Fig. 7 b). Thus, during the pre-sowing treatment with 2,25mg/l VNPs, 1mg/l SeNPs and $0,8 \mathrm{mg} / 1 \mathrm{I}-\mathrm{Se}$ nanoparticles a phytotoxic effect was observed, which manifested itself in a decrease in wheat productivity was shown.

The condition of ears and grains at bacterial and phytoplasmas infected plants wheat at pre-sowing treatment of with citrate nanoparticles of SeNPs, I-Se, VNPs and GeNPs improved has been observed (Fig. 8 B-E).

The grain weight /10 plants on variants increased at pre-treatment of citrates nanoparticles solution and infected with phytoplasmas in compared to infected plants without pre-treatment, in order: GeNPs (by two) $>$ I-Se (by two) $>$ VNPs $(29.4 \%)>$ SeNPs $(23.5 \%)$ were shown.
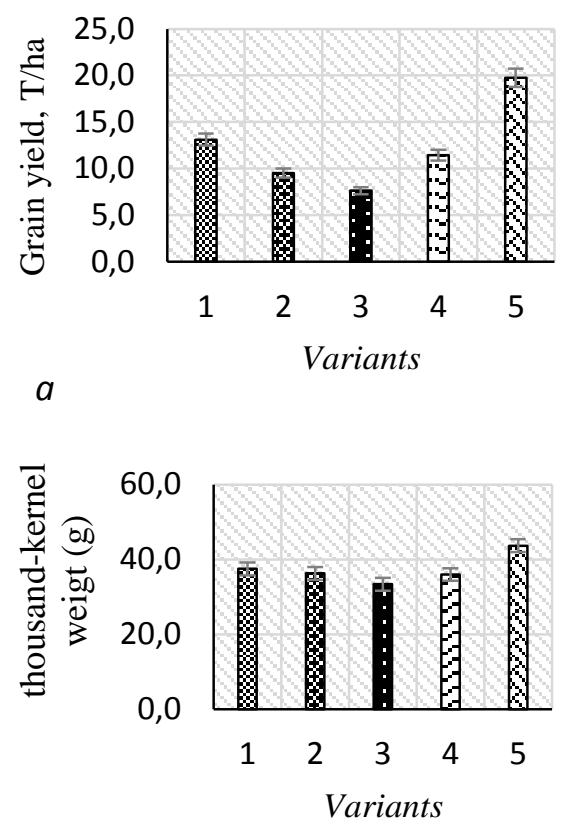

b

Figure 7. Influence of pre-treatment of wheat with citrate nanoparticles on (a) grain yield (t/ha) and thousand-kernel weight (b): 1 - Control; 2 - SeNPs; 3 - ISe; 4 - VNPs; 5 - GeNPs. 


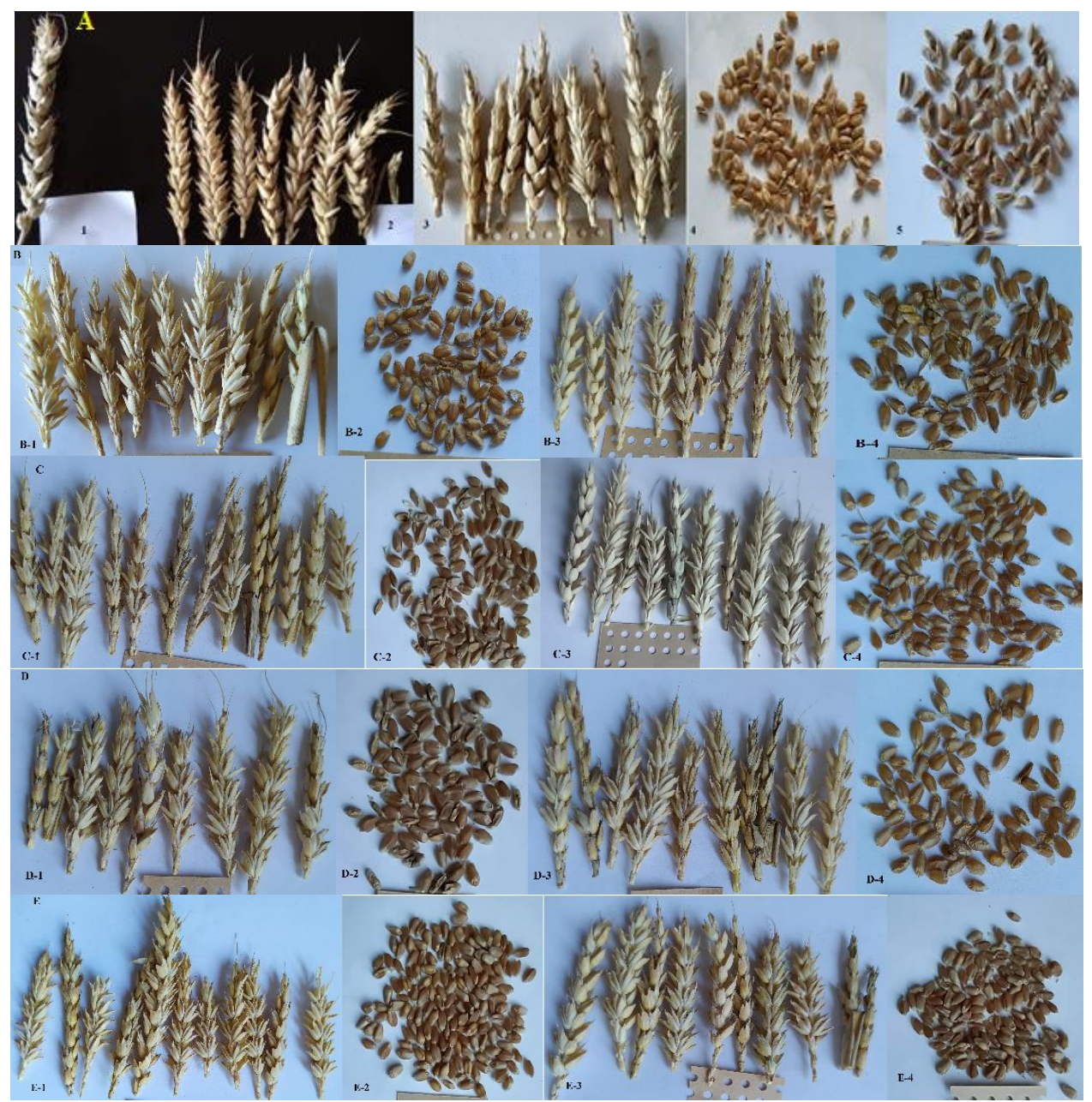

Figure 8. Ears and grains at pre-sowing treatment with citrates of nanoparticles SeNPs, I-Se, VNPs; GeNPs at bacterial and phytoplasmas infected plants: (A) 1 - Control; 2,3 - bacteriosis; 4,5 - phytoplasmosis; (B) 1,2 SeNPs+bacteriosis; 3,4 - SeNPs+phytoplasmosis; (C) 1,2 - I-Se+bacteriosis; 3,4 - I-Se+phytoplasmosis; (D) $1,2 \quad-\quad$ VNPs+bacteriosis; $3,4 \quad-$ VNPs+phytoplasmosis; (E) 1,2 - GeNPs+bacteriosis; 3,4 - GeNPs + phytoplasmosis.

Therefore, pre-sowing treatment of wheat seeds of citrate nanoparticles (2,25 mg/lVNPs, $1 \mathrm{mg} / \mathrm{lSeNPs}, 0,8 \mathrm{mg} / \mathrm{II}-\mathrm{Se}, 3,75 \mathrm{mg} / \mathrm{lGeNPs})$ with application BP Extrakon stimulated increasing the chlorophyll content and photochemical activity of leaves. An increase in the quantum efficiency of PSII was observed: at pre-sowing treatment VNPs, GeNPs, I-SeNPs at phytoplasmas infected plants, GeNPs, I-Se, VNPs at bacterial-infected plants and GeNPs,VNPs, SeNPs at WSMP-infected. 
The pre-sowing treatment nanoparticles of VNPs $(2,25 \mathrm{mg} / \mathrm{l})$, SeNPs $(1 \mathrm{mg} / \mathrm{l})$ and $\mathrm{I}-\mathrm{Se}(0,8 \mathrm{mg} / \mathrm{l})$ a phytotoxic effect was observed, which manifested itself in a decrease in wheat grain productivity was shown. At the same time, pretreatment with $3.75 \mathrm{mg} / \mathrm{L}$ GNPs, $2.25 \mathrm{mg} / \mathrm{L}$ VNPs, $1 \mathrm{mg} / \mathrm{L} \mathrm{SeNPs}$, and 0.8 $\mathrm{mg} / \mathrm{L} \mathrm{I-Se}$ increased plant resistance at bacterial and phytoplasmas infected plants, which was manifested in increasing the mass of grains and improving their quality.

This indicates an increase in stress resistance. However, an increase in grain yield was observed only in the variant of pre-sowing treatment with 3,75 $\mathrm{mg} / \mathrm{l} \mathrm{GeNPs}$.

\section{CONCLUSIONS}

The pre-sowing treatment of wheat seeds with citrate nanoparticles of VNPs, SeNPs, GeNPs and I-Se with application BP Extrakon have been favor increase the chlorophyll content in leaves has been shown.

In the field experiments, at the portable field chlorophyll fluorometer using was shown increased the quantum efficiency of PSII $(\mathrm{Fv} / \mathrm{Fm})$ at the pre-treatment of citrates of nanoparticles solution in order: GeNPs (17.5\%)>I-Se (8.8\%)>SeNPs (7.0\%). The Rfd-values increased at the pre-treatment of citrates of nanoparticles solution of GeNPs by $11.4 \%$.

At infected of wheat plants with Pseudomonas syringae pv. atrofaciens and Acholepasma laidlawii var. granulum was reduced of green weight of plants (10 pcs.) by 10,8 and 26,9\%. At the same time, plants infected at treatment with citrates GeNPs, I-Se, SeNPs, VNPs of nanoparticles had a higher biomass in comparison with the control. The most significant growth of wheat biomass on variants of the pre-treatment: GeNPs (with Extrakon) in plants with bacterial and phytoplasmas infected plants, I-Se (Extrakon) both at infected with 118 and at the mix infection $(\mathrm{D} 13+118)$ has been observed. The pre-treatment both VNPs and SeNPs (and Extrakon) was more effectiveness at infected plants of phytoplasmas has been shown.

The Fv/Fm was more at infected plants with phytoplasmas and the pretreatment of VNPs by 13.6\%. In leaves of plants at application of GeNPs and bacterial infected, the Fv/Fp-value was the more compared to control on have been shown. The Rfd-values in the leaves of plants at inoculation with phytoplasmas increased at the pre-sowing treatment of VNPs (55.6\%), GeNPs $(45.5 \%)$ and $\mathrm{I}-\mathrm{Se}(25.6 \%)$ were observed. This value increased in leaves at bacterial infected plants and the pre-sowing treatment GeNPs (12.8\%).

In greenhouse experiments was shown increased of the $\mathrm{Fv} / \mathrm{Fm}$-value on variants with the pre-treatment with: I-Se (14.7\%), VNPs (5.9\%) (at phytoplasmas infected plants), GeNPs $(42.4 \%)>\mathrm{I}-\mathrm{Se}(36.4 \%)>\mathrm{V}, \mathrm{Se}(21.2 \%)$ (at bacterial infected plants) and GeNPs $(19.6 \%)>$ VNPs (13.0\%) $>$ SeNPs (4.3\%) (at WSMV infected plants). 
The weight grains/10 in plants on the variant at the pre-treatment with $\mathrm{Ge}$ nanoparticles (with consortium of soil microorganism) with bacterial infected plants were more, than without pre-treatment has been shown.

Wheat plants on variants with pre-treatment citrates nanoparticles solution with phytoplasmas infecting was shown increased of the grain weight /10 plants, in compared to infected plants without pre-treatment, in order: GeNPs (twice) $>$ ISe (twice) $>$ VNPs $(29.4 \%)>$ SeNPs $(23.5 \%)$.

The pre-treatment with nanoparticles GeNPs caused grain production by $15.6 \%$ increased has been shown. The weight of 1000 grains increased by $16.4 \%$.

The pre-sowing treatment nanoparticles of with $2,25 \mathrm{mg} / \mathrm{l} \mathrm{VNPs}, 1 \mathrm{mg} / \mathrm{l}$ SeNPs and $0,8 \mathrm{mg} / 1 \mathrm{I}-\mathrm{Se}$ the phytotoxic effect was observed, which manifested itself in a decrease in wheat grain productivity was shown. However, we observed an improvement in grain with pre-sowing treatment with these nanoparticles and infection with pathogenic.

Thus, increase in the quantum efficiency of PSII: at pre-sowing treatment VNPs, GeNPs, I-Se (at phytoplasmas infected plants), GeNPs, I-Se, VNPs (at bacterial infected plants) and GeNPs,VNPs, SeNPs (at WSMV infected plants) has been observed. This indicates an increase in stress resistance at pre-sowing treatment with these nanoparticles. However, an increase in grain yield was observed only in the variant of the pre-sowing treatment with $3,75 \mathrm{mg} / \mathrm{l} \mathrm{GeNPs}$.

\section{REFERENCES}

Abedini, M.; Mohammadian, F. (2018) Vanadium effects on phenolic content and photosynthetic pigments of sunflower. South Western Journal of Horticulture, Biology and Environment, 9(2):77-86.

Acharya P, Jayaprakasha GK, Crosby KM, Jifon JL, Patil BS (2020). NanoparticleMediated Seed Priming Improves Germination, Growth, Yield, and Quality of Watermelons (Citrullus lanatus) at multi-locations in Texas. Sci Rep. 19;10(1):5037. doi: 10.1038/s41598-020-61696-7.

Berger S., Benediktyová Z., Matouš K., Bonfig K., Mueller M.J., Nedbal L., Roitsch T. (2007) Visualization of dynamics of plant-pathogen interaction by novel combination of chlorophyll fluorescence imaging and statistical analysis: differential effects of virulent and avirulent strains of $P$. syringae and of oxylipins on A. thaliana, Journal of Experimental Botany, 58 (4): 797-806, https://doi.org/10.1093/jxb/erl208

Chen L, Liu JR, Hu WF, Gao J, Yang JY. (2021) Vanadium in soil-plant system: Source, fate, toxicity, and bioremediation. J Hazard Mater. 2021405:124200. doi: 10.1016/j.jhazmat.2020.124200.

Davydova, N.V., Zamana, S.P., Krokhmal, I.I. et al. (2019) Spring Wheat Features in Response to Seed Treatment by Metal Nanoparticles. Nanotechnol Russia 14, 572-581. https://doi.org/10.1134/S1995078019060041Diagnose von Krankheiten und Beschädigungen an Kulturpflanzen. Diagnosemethoden. (1984) SpringerVerlag; Berlin, Heidelberg, New York, Tokyo, 204 p.

Elmer W., Ma Ch., White J. (2018) Nanoparticles for plant disease management. Current opinion in Environmental Science \& Health. 6: 66-70. https://doi.org/10.1016/j.coesh.2018.08.002 
García-Jiménez A, Trejo-Téllez LI, Guillén-Sánchez D, Gómez-Merino FC (2018) Vanadium stimulates pepper plant growth and flowering, increases concentrations of amino acids, sugars and chlorophylls, and modifies nutrient concentrations. PLoS ONE 13(8): e0201908. https://doi.org/10.1371/journal.pone.0201908Gudkov S.V., Shafeev G.A.,

Glinushkin A.P., Shkirin A.V., Barmina E.V., Rakov I.I., Simakin A.V., Kislov A.V., Astashev M.E., Vodeneev V.A., Kalinitchenko V.P. (2020) Production and Use of Selenium Nanoparticles as Fertilizers.ACS Omega. 5(28): 17767-17774 https://doi.org/10.1021/acsomega.0c02448

Gulyaeva A.B., Pasichnyk L.A., Patyka V.P. (2016) Functional activity of photosynthetic apparatus of spring wheat under action of artificial infection by pseudomonas syringae pv. atrofaciens strains of different origin. The Bulletin of Kharkiv National Agrarian University. Series Biology. 2 (38): 84-93. https://knau.kharkov.ua/uploads/visn_biology/v5/7.pdf

Haitz M., Lichtenthaler H.K. (1988) The Measurement of Rfd-Values as Plant Vitality Indices with the Portable Field Chlorophyll Fluorometer and the Pam-Fluorometer. In: Lichtenthaler H.K. (eds) Applications of Chlorophyll Fluorescence in Photosynthesis Research, Stress Physiology, Hydrobiology and Remote Sensing. Springer, Dordrecht. https://doi.org/10.1007/978-94-009-2823-7_31

Hisox JD, Israelstam RJ. (1979) The method for the extraction of chlorofill from leaf tissue whithout maceration. Can J Bot. 57(12):1332-1334. DOI: 10.1139/b79-163.

Honchar L., Mazurenko B., Shutyi O., Pylypenko V., Rakhmetov D. (2021) Effect of preseed and foliar treatment with nano-particle solutions on seedling development of tiger nut (Cyperus Esculentus L.) plants. Agronomy Research 19(S1), 767-776 https://doi.org/10.15159/AR.21.021

Hu J, Lu Q, Wu C, Liu M, Li H, Zhang Y, Yao S. Germanium nanoparticles: Intrinsic peroxidase-like catalytic activity and its biosensing applica-tion. Talanta. 2019; 195(1):407-413. https://doi. org/10.1016/j.talanta.2018.11.081Huliaieva H., Tokovenko I., Maksin V. et al. (2018) Effect of Nanoaquacitrates on Physiological Parameters of Fodder Galega Infected with Phytoplasma. Ecol Chem Eng S. 25 (1): 153-168. doi: 10.1515/eces-2018-0011

Huliaieva H.B., Tokovenko I.P., Pasichnyk L.A., Patyka V.P., Bohdan M.M., Kharchuk M.S., Maksin V.I., Patyka M.V., Kaplunenko V.G. (2020) Antimicrobial Activity of Vanadium and Germanium Nanoaquacitrates in vitro and their Physiological Effect on Wheat Plants in viv. Mikrobiol. Z. 82(6):43-53. doi: https://doi.org/10.15407/microbiolj82.06.043

Ježek P., Škarpa P., Lošák T., Hlušek J., Jůzl M., Elzner P. (2012). Selenium - An Important Antioxidant in Crops Biofortification, Antioxidant Enzyme, Mohammed Amr El-Missiry, IntechOpen, DOI: 10.5772/50356.

Khalaki A.M., Moameri, M., Asgari Lajayer, B. et al. (2021) Influence of nano-priming on seed germination and plant growth of forage and medicinal plants. Plant Growth Regul 93, 13-28 https://doi.org/10.1007/s10725-020-006709Lichtenthalera H.K., Babania F. (2000) Detection of photosynthetic activity and water stress by imaging the red chlorophyll fluorescence. Plant Physiol. Biochem. 38: 889-895.

Lichtenthaler H.K., Babani F., Langsdorf G. (2007) Chlorophyll fluorescence imaging of photosynthetic activity in sun and shade leaves of trees. Photosynth Res., 93: 235244. doi: 10.1007/s11120-007-9174-0 
Liu Y, Hou LY, Li QM, Jiang ZP, Liu D, Zhu Y. The effects of exogenous antioxidant germanium $(\mathrm{Ge})$ on seed germination and growth of Lycium ruthenicum Murr subjected to $\mathrm{NaCl}$ stress. Environ Technol. 2016;37(8):909-19. doi: 10.1080/09593330.2015.1091512.

Maxwell K., Johnson G. N. (2000) Chlorophyll fluorescence-a practical guide. Journal of Experimental Botany, $51 \quad$ (345): 659-668, https://doi.org/10.1093/jexbot/51.345.659

Medrano-Macías J., Mendoza-Villarreal R., Robledo-Torres V., Olivia Fuentes-Lara L., Ramírez- Godina F., Ángel Pérez-Rodríguez M., Benavides- Mendoza A. (2018). The Use of Iodine, Selenium, and Silicon in Plant Nutrition for the Increase of Antioxidants in Fruits and Vegetables, Antioxidants in Foods and Its Applications, Emad Shalaby and Ghada Mostafa Azzam, IntechOpen, DOI: 10.5772/intechopen.75069.

Mittal D, Kaur G, Singh P, Yadav K, Ali SA (2020) Nanoparticle-Based Sustainable Agriculture and Food Science: Recent Advances and Outlook. Front. Nanotechnol. 2:579954. doi: 10.3389/fnano.2020.579954

Mohamed T. El-Saadony, Ahmed M. Saad, Azhar A. Najjar, Seraj O. Alzahrani, Fatmah M. Alkhatib, Manal E. Shafi, Eman Selem, El-Sayed M. Desoky, Sarah E.E. Fouda, Amira M. El-Tahan, Mokhles A.A. Hassan (2021) The use of biological selenium nanoparticles to suppress Triticum aestivum L. crown and root rot diseases induced by Fusarium species and improve yield under drought and heat stress, Saudi Journal of Biological Sciences. 28 (8): 4461-4471. https://doi.org/10.1016/j.sjbs.2021.04.043

Murchie E.H., Lawson T. (2013) Chlorophyll fluorescence analysis: a guide to good practice and understanding some new applications. Journal of Experimental Botany. 64 (13): 3983-3998. doi:10.1093/jxb/ert208

Patyka V.P., Pasichnyk L.A., Gvozdyak R.I. et al. (2017): Phytopatogenni bakterii, T.2, Vinnica: TOV Vindruk

Ranoszek-Soliwoda K, Tomaszewska E, Socha E, et al. (2017) The role of tannic acid and sodium citrate in the synthesis of silver nanoparticles. J Nanopart Res. 19(8):273. doi:10.1007/s11051-017-3973-9

Pereira E.S., A.; Caixeta Oliveira, H.; Fernandes Fraceto, L.; Santaella, C. (2021) Nanotechnology Potential in Seed Priming for Sustainable Agriculture. Nanomaterials. 11, 267. https:// doi.org/10.3390/nano11020267

Perera-Castro A.V., Brito P., González-Rodríguez A.M. (2018) Changes in thermic limits and acclimation assessment of an alpine plant by chlorophyll fluorescence analysis: Fv/Fm vs. Rfd DBIOV. Botánica, Ecología y Fisiología Vegetal. Photosynthetica 56(2):527-536 DOI: 10.1007/s11099-017-0691-6

Peña-Olmos, Jaime E., Casierra-Posada, Fánor. (2013). Photochemical efficiency of photosystem II (PSII) in broccoli plants (Brassica oleracea var Italica) affected by excess iron. ORINOQUIA, 17(1), 15-22. Retrieved August 08, 2021, from http://www.scielo.org.co/scielo.php?script=sci_arttext\&pid=S012137092013000100002\&lng=en\&tlng=en

Prażak R, Święciło A, Krzepiłko A, Michałek S, Arczewska M. (2020) Impact of Ag Nanoparticles on Seed Germination and Seedling Growth of Green Beans in Normal and Chill Temperatures. Agriculture. 10(8):312. https://doi.org/10.3390/agriculture10080312. 
Rojek J, Kozieradzka-Kiszkurno MG, Kapusta MG, et al (2019) The effect of vanadium(IV) complexes on development of Arabidopsis thaliana subjected to $\mathrm{H}<\mathrm{sub}>2</$ sub $>\mathrm{O}<$ sub $>2</$ sub $>$-induced stress. Functional Plant Biology : FPB.46(10):942-961. DOI: 10.1071/fp18262.

Ruttkay Nedecky B., Krystofova O., Nejdl L., Vojtech A. (2017) Nanoparticles based on essential metals and their phytotoxicity. J Nanobiotechnol 15:33 DOI 10.1186/s12951-017-0268-3

Sanzari I., Leone A., Ambrosone A. (2019) Nanotechnology in Plant Science: To Make a Long Story Short. Front. Bioeng. Biotechnol., doi: 10.3389/fbioe.2019.00120

Sousa J.R.M., Gheyi H.R., Brito M.E.B., Lacerda C. F., Silva F.V., Soares F.A.L. (2016) Soares Quantum efficiency of photosystem II and production of orange under salt stress and nitrogen fertilization Soil, Water And Plant Management. https://doi.org/10.1590/1807-1929/agriambi.v20n5p434-440

Sharma DK, Andersen SB, Ottosen C, Rosenqvist E. (2015). Wheat cultivars selected for high Fv/Fm under heat stress maintain high photosynthesis, total chlorophyll, stomatal conductance, transpiration and dry matter. Physiologia plantarum. 153: 284-298. doi: 10.1111/ppl.12245

Shinohara S., Eom N., Thech E-J., Tamada K., Parsons D., Craig V.S. J. (2018) The Role of Citric Acid in the Stabilization of Nanoparticles and Colloidal Particles in the Environment: Measurement of Surface Forces between Hafnium Oxide Surfaces in the Presence of Citric Acid. Langmuir . 34, 8, 2595-2605 https://doi.org/10.1021/acs.langmuir.7b03116

Siddiqui, S.A., Blinov, A.V., Serov, A.V., Gvozdenko, A.A., Kravtsov, A.A., Nagdalian, A.A., Raffa, V.V., Maglakelidze, D.G., Blinova, A.A., Kobina, A.V. et al. (2021) Effect of Selenium Nanoparticles on Germination of Hordéum Vulgáre Barley Seeds. Coatings. 11, 862. https://doi.org/10.3390/ coatings 11070862

Smoleń S, Kowalska I, Czernicka M, Halka M, Kęska K and Sady W (2016) Iodine and Selenium Biofortification with Additional Application of Salicylic Acid Affects Yield, Selected Molecular Parameters and Chemical Composition of Lettuce Plants (Lactuca sativa L. var. capitata). Front. Plant Sci. 7:1553. doi: 10.3389/fpls.2016.01553Timm S, Florian A, Fernie AR, Bauwe H. (2016) The regulatory interplay between photorespiration and photosynthesis. J Exp Bot. 2016 May; 67(10):2923-9. doi: 10.1093/jxb/erw083.

Wingler A., Lea P.J., Quick W.P., Leegood R.C. (2000) Photorespiration: metabolic pathways and their role in stress protection. Phil. Trans. R. Soc. Lond. B. 355: 1517-1529 doi 10.1098/rstb.2000.0712 